\title{
Ameliorative Effects of Nano-Selenium Against Fluoride Stress Induced Hepatocytes Autophagy and Apoptosis in Mice
}

\section{Yajing Wang}

South China Agricultural University College of Economics and Management

\section{Bingxian Liu}

South China Agricultural University College of Economics and Management

Qingyue Han

South China Agricultural University College of Economics and Management

\section{Khalid Mehmood}

The Islamia University of Bahawalpur Pakistan

\section{Fazul Nabi}

Cornell University

\section{Yung-Fu Chang}

Cornell University College of Veterinary Medicine

\section{Zhaoxin Tang}

South China Agricultural University College of Economics and Management

\section{Ying Li}

South China Agricultural University College of Economics and Management

Hui Zhang ( $D$ hz236@scau.edu.cn )

South China Agricultural University College of Economics and Management https://orcid.org/00000002-1700-5065

\section{Research}

Keywords: Fluorosis, Nano-Se, Autophagy, Apoptosis, Hepatotoxicity

Posted Date: July 23rd, 2020

DOl: https://doi.org/10.21203/rs.3.rs-44205/v2

License: (c) (1) This work is licensed under a Creative Commons Attribution 4.0 International License.

Read Full License 
The authors have withdrawn this preprint from Research Square 